\title{
Efficacy of indigenous plant growth- promoting rhizobacteria and Trichoderma strains in eliciting resistance against bacterial wilt in a tomato
}

Narasimhamurthy Konappa', Soumya Krishnamurthy², Udayashankar C. Arakere ${ }^{1 *}$, Srinivas Chowdappa ${ }^{3}$ and Niranjana Siddapura Ramachandrappa'

\begin{abstract}
Bacterial wilt of tomato caused by Ralstonia solanacearum is a serious threat to tomato production worldwide. For eco-friendly management of bacterial wilt of tomato, the rhizospheric microorganisms belonging to the genera Bacillus (6 isolates), Brevibacillus (1 isolate), Pseudomonas (3 isolates), and Trichoderma (8 isolates) were studied for their ability to induce innate immunity in tomato, individually and in combination against $R$. solanacearum in greenhouse and field studies. In laboratory studies, maximum germination percent of 93\%, vigor index of 1609 was noted in seed bacterization with P. fluorescens Pf3, followed by $91 \%$ germination, vigor index of 1593 in treatment with T. asperellum T8 over control. Under greenhouse conditions, protection against bacterial wilt in individual treatments with PGPRs ranged from 38 to 43\% and Trichoderma sp. ranged from 39 to $43 \%$ in comparison to control. In comparison to individual seed treatment, among different combinations, maximum seed germination percent of $97 \%$ was recorded with combination P. fluorescens Pf3 + T. longibrachiatumUNS11. In greenhouse studies' combination seed treatment with $P$. fluorescens Pf3 + T. longibrachiatumUNS11 offered an impressive 62\% protection against bacterial wilt over control. Similarly, under field conditions, seed treatment with P. fluorescens Pf3 $+T$. longibrachiatumUNS11 resulted in $61 \%$ protection. The innate immunity triggered by eco-friendly seed treatment was analyzed by expression to defense-related enzymes such as peroxidase, phenylalanine ammonialyase, and polyphenol oxidase in comparison to control. This study indicated that the potential benefits of using combination treatments of beneficial microorganisms in effectively inducing resistance are possible for dual benefits of enhanced plant growth, tomato yield, and pathogen suppression.
\end{abstract}

Keywords: Ralstonia solanacearum, Seed treatments, Tomato, Combinations, Defense enzymes, Trichoderma, PGPR

\section{Background}

Tomato (Solanum lycopersicum L.) is one of the greatest economically significant solanaceous vegetable developed worldwide and major crop after sweet potato and potato. India positions second in tomato production worldwide (Prajapati et al. 2014). Tomato plants are

\footnotetext{
* Correspondence: acudayashankar@gmail.com

'Department of Studies in Biotechnology, University of Mysore,

Manasagangotri, Mysore, Karnataka 570 006, India

Full list of author information is available at the end of the article
}

susceptible to more than 200 diseases caused by bacteria (bacterial wilt, bacterial canker, bacterial speck, and bacterial leaf spot), fungi (Fusarium wilt, Verticillium wilt, root rot, Alternaria stem canker, powdery mildew, etc.), and viruses (tomato mosaic virus, tomato spotted wilt virus, and tomato yellow leaf curl virus) (Nowicki et al. 2013). Among these diseases, bacterial wilt incited by Ralstonia solanacearum is one of the devastating infections of tomato crops in the tropical and subtropical areas of the world (Wei et al. 2018). Based on the 
economic and scientific position in plant pathogens, among the top 10 bacterial pathogens, $R$. solanacearum placed as the second most bacterial pathogen that causes a vascular wilt and is one of the most damaging pathogens with rapid and fatal wilting symptoms (Mansfield et al. 2012).

$R$. solanacearum is the soil-borne bacterial phytopathogen, and its varied host variety causes wilt in more than 450 plant species in 54 families (Milling et al. 2011). The wilt limits the production of numerous crops such as tomato, eggplant, ginger, potato, chilli, banana, and groundnut in India (Narasimha Murthy and Srinivas 2012; Mansfield et al. 2012). The bacterial wilt has been reported mostly from tropical, subtropical, and warm temperate areas including Karnataka, Andhra Pradesh, Odisha, Kerala, Goa, West Bengal, Maharashtra, Assam, Jharkhand, Himachal Pradesh, Uttarakhand, etc. (Devendra et al. 2018). R. solanacearum grows in vascular systems of hosts that are responsible for symptoms of wilt. The presence of the $R$. solanacearum inside the xylem is multiplied with the production of extracellular polysaccharides which block the vascular vessels inducing a water shortage throughout the plant.

The control of bacterial wilt in tomato has been difficult because it has a wide host range, limited possibility for chemical control, long survival rate in soil, and genetic diversity of $R$. solanacearum (Elphinstone 2005). Presently, bactericide application is one of the greatest approaches for control of bacterial wilt and a variety of antibiotics are available (Yuliar et al. 2015). Increasing the usage of synthetic bactericides for control of wilt causes numerous detrimental effects on human health and environment (Satapute et al. 2019). Due to the hazards associated with synthetic pesticides, disease managements through biological control are the new developing knowledge and gaining significance in well farming sustainability (De-Britto et al. 2020). Biological agents, well defined as living microorganisms, can expressively decrease the plant pathogen density (O'Brien 2017). Certain bacteria and fungi are discussed as plant growth-promoting rhizobacteria (PGPR) and plant growth-promoting fungi (PGPF), respectively, and their efficacy in controlling various plant diseases affected by plant pathogens has been extensively recognized (Abdelrahman et al. 2016 and Zhang et al. 2020). Induced systemic resistance (ISR) is an improvement of plant selfprotective capability against different phytopathogens (Romera et al. 2019).

Numerous beneficial microbes can induce defense reaction and decrease disease frequency in various hostpathogen interactions (Kloepper et al. 2004). These PGPRs and PGPFs trigger plant defense mechanisms against plant pathogens by improving the defense enzymes like peroxidase (POX), phenylalanine ammonialyase (PAL), and polyphenol oxidase (PPO). Combined applications of two or more beneficial microbes are more active in controlling the plant diseases than using an individual microorganism (Maketon et al. 2008). The combination method had an advantage in several features to the single strains such as a wider range activity, more consistent biocontrol effectiveness, and a more defense activity (Latha et al. 2009).

Hence, the present study was conducted to analyze the ability of PGPR and Trichoderma strains in improving seed germination and seedling vigor under laboratory conditions and the effect of selected PGPR and Trichoderma strains individual and with combined seed treatment in the induction of resistance under greenhouse and field studies. The ability of strains in inducing resistance was analyzed by the activity of defense-related enzymes in treated and control seedlings.

\section{Materials and methods}

\section{PGPR, Trichoderma strains, and inoculum preparation}

Plant growth-promoting rhizobacterial strains ( $P$. fluorescens) and Trichoderma sp. were isolated from rhizosphere soil on nutrient agar (NA) medium (Hi MediaMumbai) and potato dextrose agar medium (PDA) ( $\mathrm{Hi}$ Media-Mumbai), respectively, by serial dilution method (Narasimha Murthy et al. 2013 and McPherson et al. 2018). A total of 18 bacterial strains and Trichoderma sp. were used in the present study. Among the 18 bacterial strains, 6 strains of Bacillus sp., one strain of Brevibacillus sp., 3 strains of $P$. fluorescens, and 8 strains Trichoderma sp., 7 PGPRs, B. amyloliquefaciens IN937a, B. subtilis GB03, B. subtilis SE34, B. pumilusT4, Brevibacillus brevis IPC11, B. subtilis IN937b, and Bacillus pumilus INR7 were obtained from culture collections of the Department of Entomology and Plant Pathology, Auburn University, Alabama (courtesy of Professor Kloepper J.W and Professor M.S. Reddy). Pseudomonas fluorescens Pf3 (KF679344), P. fluorescens Pf5 (KF679345), P. fluorescens Pf8 (KF679346), Trichoderma asperellum T4 (KF679342), $T$. asperellum $\mathrm{T} 8$ (KF679343), T. harzianum UNS10 (MK611661), T. harzianum UNS35 (MK611662), T. longibrachiatum UNS11 (MK611663), T. longibrachiatum UNS11 (MK611664), T. viride UNS35 (MK886525), and T. viride UNS42 (MK886526) were isolated and molecular identification from different rhizosphere soil.

Bacterial cell suspensions were prepared by growing in 500-ml conical flasks having a 200-ml nutrient broth (NB) medium (Hi Media-Mumbai) on a shaker at 120 rpm at $28 \pm 2{ }^{\circ} \mathrm{C}$ for $24 \mathrm{~h}$. The cells were harvested by centrifuging at $6000 \mathrm{rpm}$ for $5 \mathrm{~min}$, and the bacterial pellet was re-suspended in distilled water and was adjusted to OD 0.1 at $600 \mathrm{~nm}$ by a UV-visible spectrophotometer (Elico-Japan) to get a $1 \times 10^{8} \mathrm{cfu} / \mathrm{ml}$. For the preparation of Trichoderma sp. inoculum, a 7-day-old culture on 
PDA agar (HiMedia-Mumbai) plates were harvested by the addition of $10 \mathrm{ml}$ of sterile distilled water and gently brushing the culture surface by a bent sterile glass rod. The cell suspension was filtered by using double-layered cheesecloth to eliminate large mycelial remains. The concentration of spore was assessed by hemocytometer, and $5 \times 10^{9}$ spores $/ \mathrm{ml}$ was used. The Trichoderma spores were mixed with sterilized talc powder, and the final concentration of the carrier material per gram was $5 \times 10^{9}$ spores per gram. After shade dry, the talc formulation was filled in a polypropylene bag and closed (Jayaraj et al. 2006).

\section{Preparation of $R$. solanacearum inoculum}

The $R$. solanacearum (RS5-KF924743) inoculum was prepared by the inoculation of a pathogen in casamino acid peptone glucose (CPG) broth (Hi Media-Mumbai) and incubated for $48 \mathrm{~h}$ on a rotary shaker at $150 \mathrm{rpm}$ at $30{ }^{\circ} \mathrm{C}$. The bacterial cells were harvested in sterile distilled water by centrifugation at $12,000 \mathrm{rpm}$ at $10^{\circ} \mathrm{C}$ for $10 \mathrm{~min}$. The $R$. solanacearum cell pellet was resuspended in sterilized distilled water, bacterial concentration was adjusted to $1 \times 10^{8} \mathrm{cfu} / \mathrm{ml}$, and absorbance was adjusted absorbance at $600 \mathrm{~nm}$ using UV-visible spectrophotometer (Elico-Japan) (Ran et al. 2005).

\section{Mode of seed treatment}

One gram of tomato seeds (Arka Meghali) was surfacesterilized with $10 \mathrm{ml}$ of $1 \%(\mathrm{v} / \mathrm{v})$ sodium hypochlorite for $3 \mathrm{~min}$, washed thoroughly twice in distilled water, and shade dry on a blotter sheet. Bacterization of the surface-sterilized tomato seeds was attained by soaking in bacterial suspensions, preparation of bacterial suspensions as described earlier and added with $0.2 \%$ sterilized carboxymethyl cellulose (CMC) as a sticker. The bacterial suspensions were incubated at $26^{\circ} \mathrm{C}$ in a shaker for 6 $\mathrm{h}$ to bind the bacterial cells to the seed coat. After incubation, the seeds were allowed to shade dry. The seeds treated with distilled water modified with CMC served as a control. Strains of Trichoderma sp. in talc powder formulation was prepared by aseptically mixing $400 \mathrm{ml}$ of $5 \times 10^{9}$ spores, with $1 \mathrm{~kg}$ of earlier sterilized talc powder. The talc powder was autoclaved at $121{ }^{\circ} \mathrm{C}$ for 30 min on two successive days and mixed with $0.2 \% \mathrm{CMC}$ prior to seed treatment, and the seed was mixed with the Trichoderma sp. formulation at $15 \mathrm{~g} / \mathrm{kg}$ of seeds.

\section{Effect of PGPR and Trichoderma sp. on seed germination} and seedling vigor of tomato under laboratory conditions The germination test was conducted based on the paper towel method using seeds treated with pure PGPR suspensions and Trichoderma sp. spores as described earlier (ISTA 2003). Treated and control seeds were seeded onto paper towels rinsed in a sterilized distilled water.
One hundred tomato seeds were positioned equidistantly on a paper towel and enclosed with another pre-soaked paper towel, rolled along with the polythene packaging to avoid drying of towels. The rolled paper towels were then incubated in an incubation chamber at $24 \pm 1{ }^{\circ} \mathrm{C}$. After incubation, the paper towels were opened and the number of germinated seeds was recorded and signified as the percent. The seedling vigor index was calculated after 10 days of incubation (Abdul Baki and Anderson 1973). To evaluate the vigor index, the mean length of the root and shoot in each variant of inoculation were measured. The vigor index (VI) was calculated using the formula VI = (mean root length + mean shoot length $) \times$ germination percent. The experimentation was conducted with four replicates of hundred seeds each, and the entire experiment was repeated thrice.

\section{Screening of PGPR and Trichoderma sp. against bacterial wilt disease under greenhouse conditions}

In greenhouse conditions, the treated seeds were planted in sterilized plastic pots (25-cm diameter) with soil mixtures (soil: sand: farmyard in the ratio of 1:1:1). The pots were kept under greenhouse conditions such as day and night cycles of 16 and $8 \mathrm{~h}$ and 28 and $30{ }^{\circ} \mathrm{C}$ and $65 \%$ relative humidity. Each treatment contained five replicates, with 20 seedlings per replicate. In the seedling stage, 3 seedlings were kept in each pot. The 20-day-old plant root system of each plant was wounded with a scalpel, and the seedlings were challenge-inoculated by soil drenching at $30 \mathrm{ml}$ of $1 \times 10^{8} \mathrm{cfu} / \mathrm{ml}$ of $R$. solanacearum suspension into the wounded root system of each pot (Tans-Kersten et al. 2001). Seed treatment with distilled water served as a control. Treated plants were observed for bacterial wilt indications after challenge inoculation, and wilt incidence was documented up to 30 days. Wilting incidence (\%) was calculated, following the formula: $\mathrm{WI} \%=(\mathrm{Nw} / \mathrm{Nt}) \times 100$, where $\mathrm{Nw}=$ number of wilted plants and $\mathrm{Nt}=$ total number of plants.

\section{Effect of combination seed treatment with PGPR and Trichoderma sp. on seed germination and vigor of tomato seedling}

Based on seed germination, seedling vigor and greenhouse studies, the potential 7 isolates were selected for combination study (3 PGPR strains and 4 strains of Trichoderma sp.) viz., B. subtilis SE34, B. amyloliquefaciens IN937a, P. fluorescens Pf3, T. asperellum T8, T. harzianum UNS35, T. longibrachiatum UNS11, and T. viride UNS42. The seed germination test was carried out based on the paper towel method; seeds treated with selected both bacterial suspensions and Trichoderma sp. spores in 4 replicates of 100 seeds each (ISTA, 2003). The germination test was performed as defined earlier. 
Effect of combination seed treatment with PGPR and Trichoderma sp. on bacterial wilt under greenhouse conditions

The combination treatments were similar as designated above. In greenhouse experiments, the treated seedlings were transplanted in sterilized plastic pots $(25-\mathrm{cm}$ diameter) with soil mixtures (soil: sand: farmyard in the ratio of 1:1:1). Each treatment contained 5 replicates, with 20 seedlings per replicate, with three repeated experiments. In the seedling stage, only 3 plants were kept in each pot. Twenty-day-old seedlings were challenge-inoculated with $30 \mathrm{ml}$ of $R$. solanacearum suspension by soil drenching into every pot. Treated seeds with distilled water served as control. Plants were observed for bacterial wilt symptoms after challenge inoculation, and wilt incidence was recorded up to 30 days.

\section{Effect of combination seed treatment with PGPR and Trichoderma sp. on bacterial wilt incidence under field conditions}

The field experiment was carried out at farming plots located in Bhoomishettihalli $(\mathrm{BH})\left(13^{\circ} 28^{\prime} 05.7^{\prime \prime} \mathrm{N}, 78^{\circ}\right.$ 04' 57.7" E), Karnataka, India, during tomato growing season of March to June in 2018. The treatments and controls were the same as those given above. Twentyday-old-treated tomato seedlings were uprooted from portrays and transplanted to trial plots with a spacing of $60 \times 45 \mathrm{~cm}$. The selected individual experimental plot size was of $25 \mathrm{~m}^{2}$ (Narasimha Murthy et al. 2016). Two weeks after transplantation, challenge inoculation with $R$. solanacearum suspension ( $5 \mathrm{ml} /$ plant) by soil drenching method. Each treatment has 4 replications, and each repetition contained 100 seedlings. All the cultural procedures, application of fertilizers, etc., were followed as per the package of practices. The percentage of bacterial wilt frequency was recorded 1 week to 45 days after pathogen inoculation. Tomato fruits were periodically harvested and evaluated at average fruit weight and tomato yield per plot was transformed to $\mathrm{kg} / \mathrm{m}^{2}$ (Wydra and Semrau 2005).

\section{Sample collection for enzyme analysis}

The leaf samples of single- and combined-treated plants were sampled at $0,6,12,24,36,48,60,72,84$, and $96 \mathrm{~h}$ after challenge inoculation with $R$. solanacearum and kept at $-80^{\circ} \mathrm{C}$ until used for the following study. The treatments were included under the greenhouse: (1) inoculated control (IC) (inoculated with R. solanacearum), (2) un-inoculated control (UC), and (3) seedlings grown from seed treated with individual and combination of PGPR and Trichoderma sp. One gram of leaves of tomato was homogenized with $2 \mathrm{ml}$ of $0.1 \mathrm{M}$ sodium phosphate buffer ( $\mathrm{pH} 7.0)$ at $4{ }^{\circ} \mathrm{C}$ in mortar and pestle, and the homogenate was centrifuged at $12,000 \mathrm{rpm}$ for 20 min. The homogenate supernatant was used as a crude extract for enzymes analysis of peroxidase (POX) (EC 1.1 1.1.7) and polyphenol oxidase (PPO) (E.C. 1.14.18.1) (Narasimha Murthy et al. 2016). The POX and PPO enzyme activities were expressed as changes in the absorbance $\mathrm{min}^{-1} \mathrm{mg}^{-1}$ of fresh tissue. Protein estimations of extracts were carried out by Lowry's method using bovine serum albumin as a standard (Lowry 1951).

\section{Statistical analyses}

The experiments were carried out in triplicates and results were calculated as mean \pm standard deviation. The analysis was performed with ANOVA and Duncan multiple range test (DMRT) test was done using SPSS software (version 20.0). The differences were measured as important when $p \leq 0.05$.

\section{Results and discussion}

Effect of PGPR and Trichoderma sp. on seed germination and seedling vigor of tomato under laboratory conditions The results of the percent of seed germination revealed that all the seed treatments had improved seed germination and seedling vigor than the control. The germination percent of tomato seeds treated with PGPR strains and treated Trichoderma sp. ranged from 93 to $81 \%$ and 91 to $86 \%$, respectively. Among PGPR treatments, $P$. fluorescens $\mathrm{Pf} 3$ showed maximum germination percent (93\%), followed by B. amyloliquefaciens IN937a (92\%), B. subtilis SE34 (91\%), P. fluorescens Pf5 (90\%), B. subtilis GB03 and P. fluorescens Pf8 (88\%), B. subtilis IN937b (87\%), Bacillus pumilusINR7 and Brevibacillus brevis IPC11 (86\%), and B. pumilusT4 (85\%) germination as compared to control (81\%) germination (Fig. 1). Among Trichoderma sp. treatments, maximum germination percent of 91\% was observed in with Trichoderma asperellum T8, T. viride UNS35, and T. harzianum UNS35, followed by $T$. longibrachiatum UNS11 (90\%), T. viride UNS42 (89\%), T. longibrachiatum UNS28 (88\%), T. asperellum T4 (87\%), and T. harzianum UNS10 (86\%) as compared to control (81\%). The vigor index of tomato seedlings ranged from 1609 to 1273 with PGPR treatments and with Trichoderma sp. ranged from 1593 to 1324 vigor indexes as compared to control (1110). Among 10 PGPR strains, the maximum seedling vigor index was recorded in seed bacterization by $P$. fluorescens Pf3 (1608.9) and among 8 Trichoderma sp., highest vigor index was recorded by $T$. asperellum T8 (1592.5) (Fig. 1).

In the present study, seed treatments with various PGPRs and Trichoderma isolates, either individually or combined, significantly improved germination and vigor index in comparison to control. The above outcomes might be due to the improved production of plant hormones such as gibberellins would have elicited the 


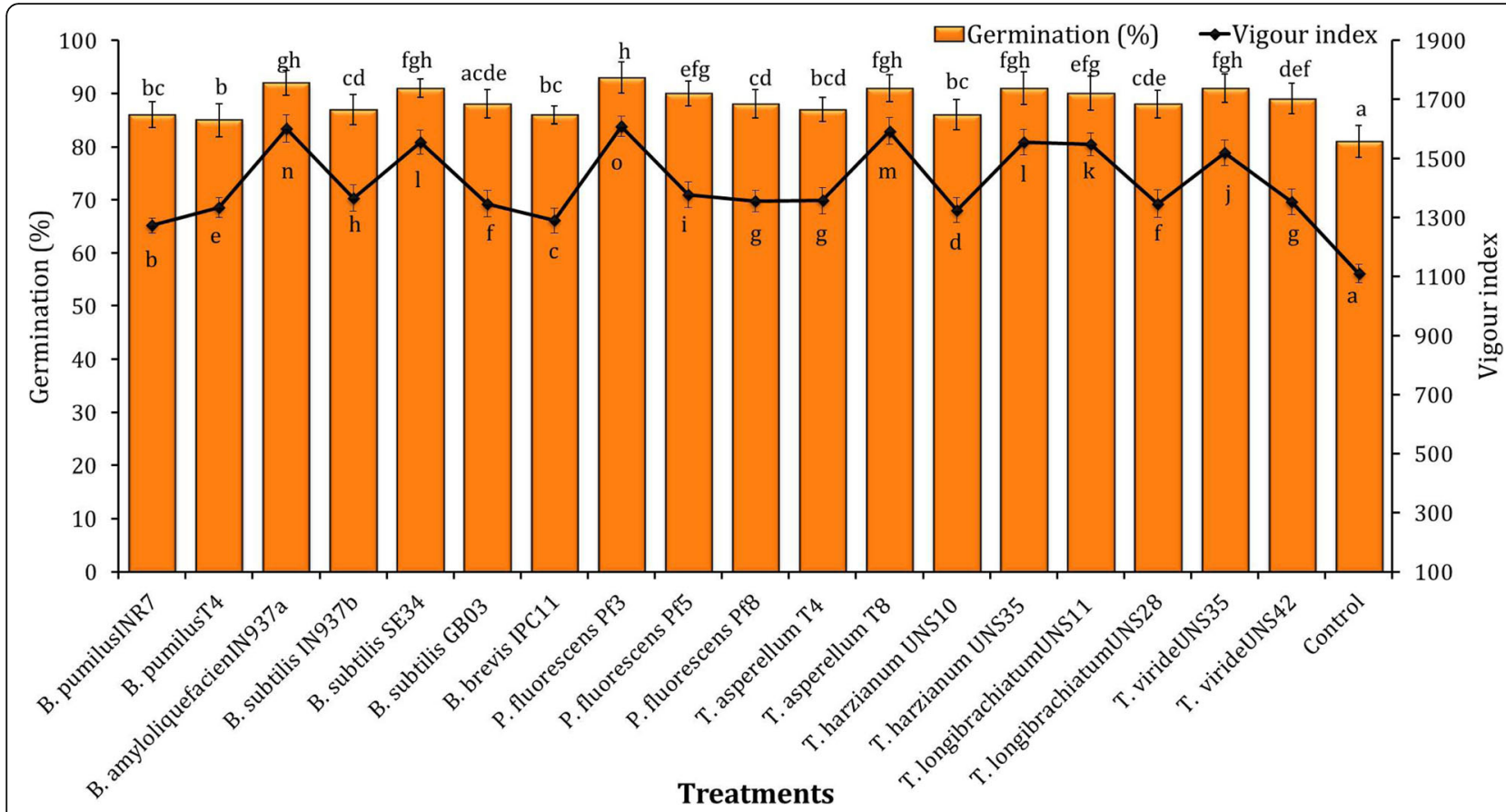

Fig. 1 The effect of PGPR and Trichoderma strains treatment on seed germination and seedling vigor of tomato under laboratory conditions. Means of three replications, followed by the letters according to Duncan's multiple range tests (DMRT). Means sharing different alphabetical (a-o) in a column significantly different $(P<0.05)$

action of specific enzymes that helped initial germination, like amylase has supported an increase in accessibility of starch assimilation. These research outcomes are in promise with Almaghrabi et al. (2013) which improved plant growth, shoot weight, root weight, plant height, number of fruits per plants, and weight of yield per plant by treatment of $P$. putida, $P$. fluorescence, $S$. marcescens, B. amyloliquefaciens, B. subtilis, and B. cereus. Similar studies have described improved plant growth and development in inoculated with PGPR (VanLoon 2007; Boudyach et al. 2010).

\section{Screening of PGPR and Trichoderma sp. against bacterial wilt disease under the greenhouse conditions}

Among PGPR and Trichoderma strains assessed individually for their efficiency to induce resistance against bacterial wilt disease incidence, varied degrees of protection, ranging $38-43 \%$ under greenhouse conditions. Bacterial wilt disease incidence of $54 \%$ ( $43 \%$ protection) was resulted by treated with $P$. fluorescens $\mathrm{Pf} 3$ and $B$. amyloliquefaciens IN937a in comparison with non-bacterized control (97\% bacterial wilt incidence) (Table 1). Similarly, seed treatment with $T$. asperellum $T 8, T$. harzianum UNS35, and T. viride UNS42 resulted in 54, 54, and $55 \%$ bacterial wilt disease incidence, respectively, and disease protection resulted as 43,42 , and $42 \%$, respectively, in comparison to control (97\%) (Table 1). The soil application of B. amyloliquefaciens (S13-3) inhibited bacterial wilt in tomato overproduction of antibiotics increased by induction of systemic resistance (Shoko et al. 2014).

B. amyloliquefaciens strains (CM-2 and T-5) were induced with many defense responses in a tomato plant, resulting in the control of bacterial wilt (Tan et al. 2013). The treatment of roots of tomato seedlings with B. thuringiensis isolate, followed by the challenged with $R$. solanacearum inhibited the wilt symptom development and induction of defense system in tomato, counting the gene expression of pathogenesis-related proteins (Hyakumachi et al. 2013).

\section{Effect of combination seed treatment with PGPR and Trichoderma sp. strains on seed germination and vigor of tomato seedling}

The combination of PGPR and fungal strain-treated seeds revealed all the treatments showed improved seed germination percentage, vigor index as compared to control (Fig. 2). The seed germination percent and vigor index presented by a combination of PGPR and Trichoderma strains were greater in comparison to straintreated alone and control (82\%). Among combination seed treatment, the highest seed germination percent of 97\% was recorded in treatment with $P$. fluorescens Pf3 + T. longibrachiatum UNS11 combination, followed by 96\% with P. fluorescens Pf3 $+T$. harzianum UNS35. Treatment with $B$. subtilis SE34 + T. viride UNS42, $P$. 
Table 1 Screening of PGPR and Trichoderma strains for their potential to induce resistance against bacterial wilt under greenhouse conditions

\begin{tabular}{lll}
\hline Treatments & Disease incidence (\%) & Disease protection (\%) \\
\hline Bacillus pumilus INR7 & $59.6^{\mathrm{k}}$ & $37.8^{\mathrm{b}}$ \\
B. pumilus T4 & $57.6^{\mathrm{fgh}}$ & $39.8^{\mathrm{cde}}$ \\
B. amyloliquefaciens IN937a & $54.6^{\mathrm{abc}}$ & $42.8^{\mathrm{hij}}$ \\
B. subtilis IN937b & $58.7^{\mathrm{jjk}}$ & $38.7^{\mathrm{bc}}$ \\
B. subtilis SE34 & $56.4^{\mathrm{de}}$ & $41.0^{\mathrm{fg}}$ \\
B. subtilis GB03 & $57.5^{\mathrm{fg}}$ & $39.9^{\mathrm{de}}$ \\
BrevibacillusbrevisIPC11 & $59.3^{\mathrm{jk}}$ & $38.1^{\mathrm{b}}$ \\
P. fluorescens Pf3 & $54.3^{\mathrm{ab}}$ & $43.1^{\mathrm{ij}}$ \\
P. fluorescens Pf5 & $58.6^{\mathrm{hijk}}$ & $38.8^{\mathrm{bcd}}$ \\
P. fluorescens Pf8 & $57.7^{\mathrm{fghi}}$ & $39.7^{\mathrm{cde}}$ \\
T. asperellum T4 & $58.4^{\mathrm{ghij}}$ & $39.0^{\mathrm{cde}}$ \\
T. asperellum T8 & $54.1^{\mathrm{a}}$ & $43.3^{\mathrm{j}}$ \\
T. harzianum UNS10 & $57.2^{\mathrm{ef}}$ & $40.2^{\mathrm{ef}}$ \\
T. harzianum UNS35 & $54.8^{\mathrm{abc}}$ & $42.6^{\mathrm{hij}}$ \\
T. Iongibrachiatum UNS11 & $55.6^{\mathrm{cd}}$ & $41.8^{\mathrm{gh}}$ \\
T. longibrachiatum UNS28 & $57.4^{\mathrm{efg}}$ & $40.0^{\mathrm{e}}$
\end{tabular}

Means of three replications, followed by the letters according to Duncan's multiple range tests (DMRT). Means sharing different alphabetical (a-k) superscripts in a column significantly different $(P<0.05)$. Control $R$. solanacearum-treated plants

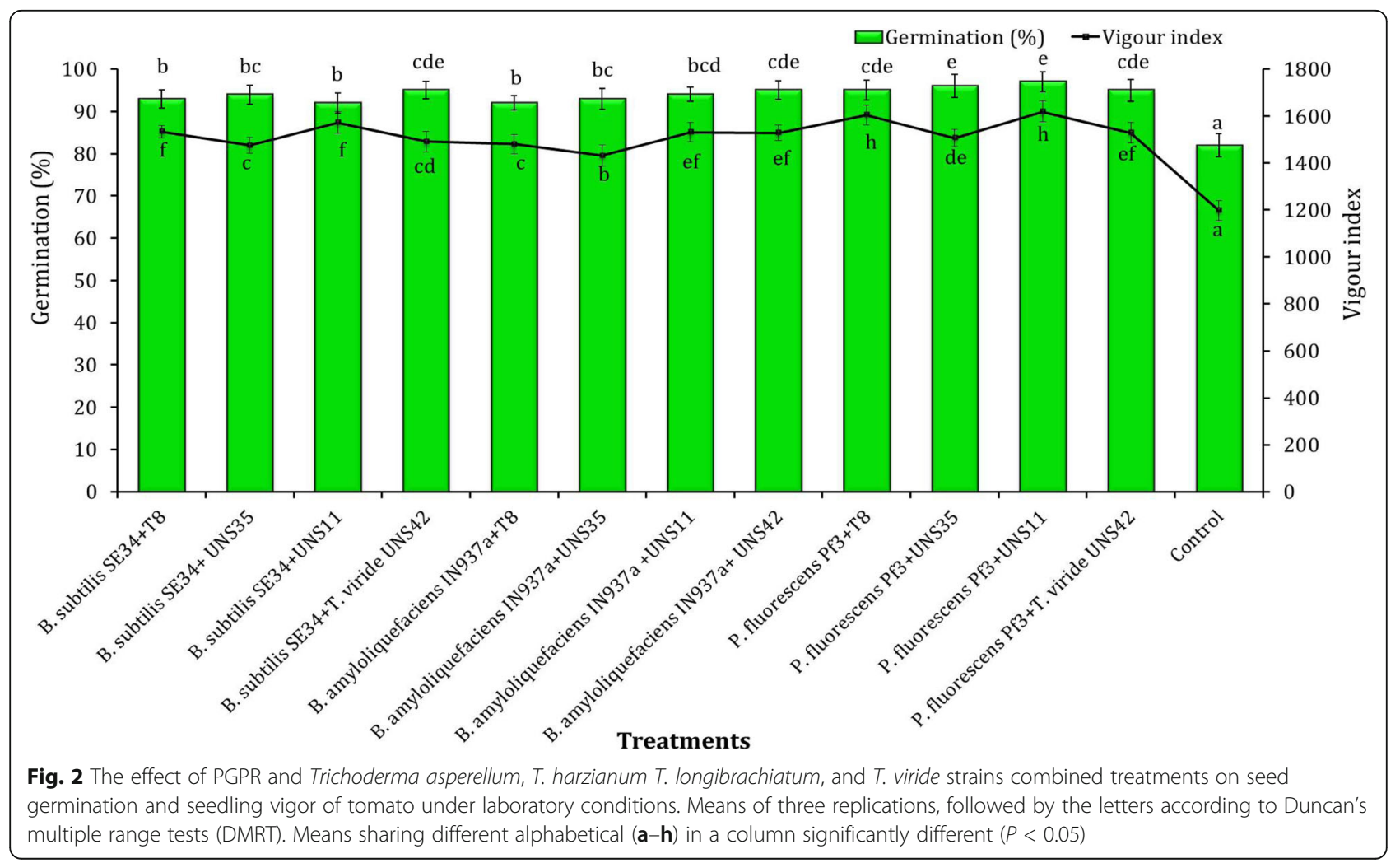


fluorescens Pf3 + T. asperellum $\mathrm{T} 8$, and P. fluorescens $\mathrm{Pf} 3+T$. viride UNS42 resulted in seed germination of 95\% with comparison to control. Treatment with B. subtilis SE34 + T. harzianum UNS35 and B. amyloliquefaciens IN937a $+T$. longibrachiatum UNS11 resulted in seed germination of 94\%. Similarly, treatment with $B$. subtilis SE34 + T. asperellum T8 and B. amyloliquefaciens IN937a $+T$. harzianum UNS35 resulted in 93\% germination. Combination treatments with B. subtilis SE34 + T. longibrachiatum UNS11 and B. amyloliquefaciens IN937a + T. asperellum T8 resulted in 92\% seed germination in comparison to control (82\%) (Fig. 2). Seed treatments with a combination of strains improved vigor index in comparison to un-inoculated control (1197.2). Maximum vigor index of 1605.5 and 1619.9 was recorded in P. fluorescens Pf3 $+T$. asperellum T8 and $P$. fluorescens $\mathrm{Pf} 3+T$. longibrachiatum UNS11, respectively (Fig. 2). Present results agreed with the AboElyousr et al. (2019) reported that seed primed with $B$. subtilis, B. amyloliquefaciens, $P$. fluorescens, and P. aeruginosa increased the seed germination up to $90.0 \%$.

\section{Effect of seed treatment combination with PGPR and Trichoderma sp. on bacterial wilt under the greenhouse conditions}

Complete valuation of wilt protection presented by the combination of both PGPR and Trichoderma sp. were significantly higher than wilt protection presented by strains treated individually (Fig. 3). A combination of $P$. fluorescens $P f 3+T$. longibrachiatum UNS11 was found wilt protection of $62 \%$ as compared to control and other combinations (Table 2).

In the present study, results were found that a combination of PGPR and Trichoderma strains had higher disease control than those of single-treated strains. A total of 12 consortia of PGPR and Trichoderma sp. were studies under the greenhouse and field conditions against bacterial wilt of tomato. The combined applications of PGPR and Trichoderma strains have reported to be effective under field conditions against bacterial wilt of tomato. Field trial outcomes evidently confirm that the treatment of PGPR and Trichoderma sp. as potential inducers in inducing resistance in tomato plants against bacterial wilt. The treatments of $P$. fluorescens $\mathrm{Pf} 3+T$. longibrachiatum UNS11 were recorded highest wilt protection of $62 \%$ as compared to control treatment (97\%). Our research outcomes authenticate earlier reports that in the control of bacterial wilt, the use of beneficial microbes in combination treatments was more effective than individual agents (Thilagavathi et al. 2007 and Elsayed et al. 2020). The present results agreed with the $R$. solanacearum wilt disease reduction in tomato plants by treatment with Bacillus sp. and P. fluorescens described by Guo et al. (2004). Rahman et al. (2018)

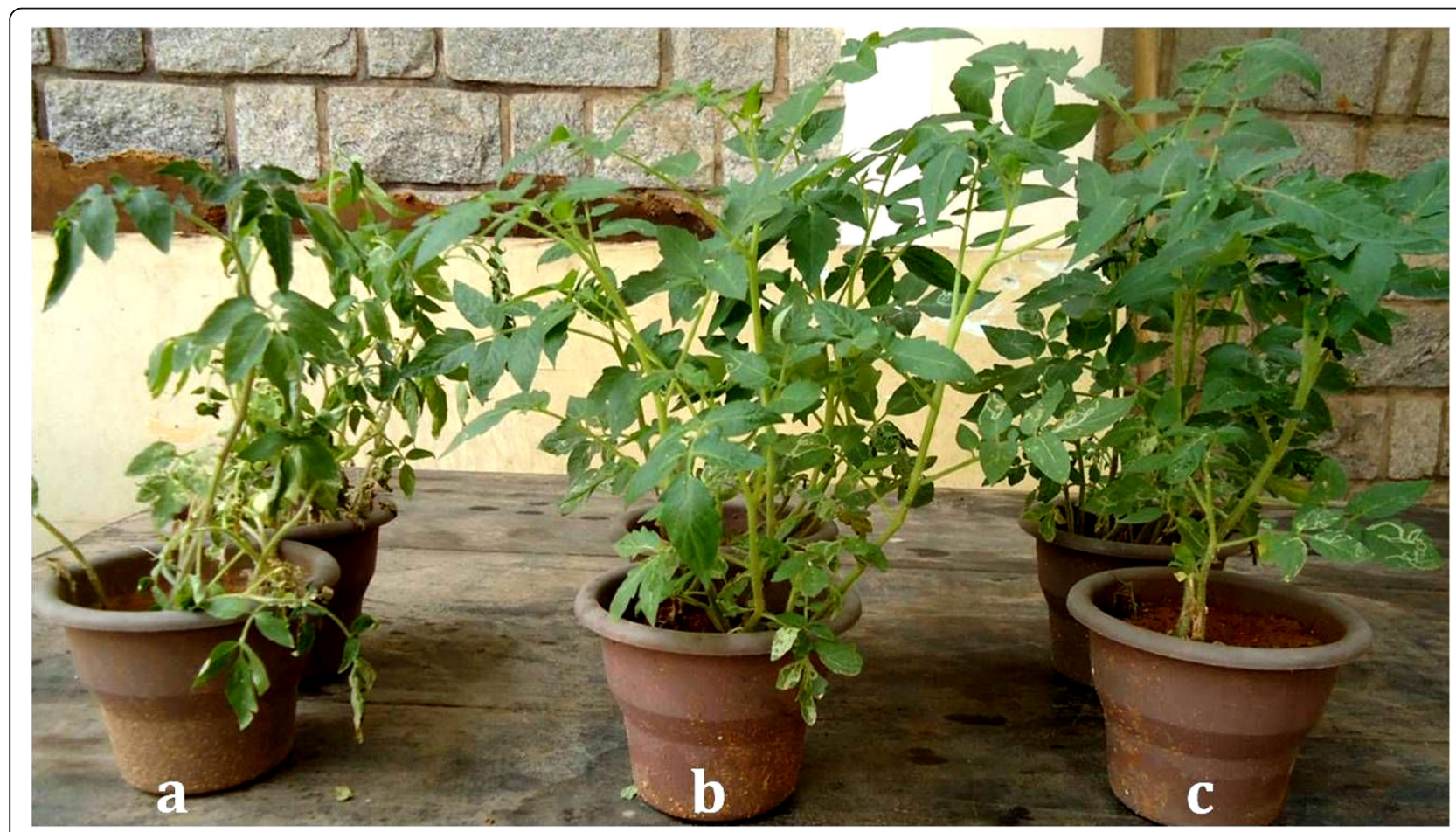

Fig. 3 The effect of combined seed treatment with PGPR and Trichoderma strains on the induction of resistance against bacterial wilt in tomato under greenhouse conditions. a Control. b Combined treatment with B. amyloliquefaciens IN937a+ T. Iongibrachiatum UNS11. c Combined treatment with $P$. fluorescens Pf3+ T. longibrachiatum UNS11 
Table 2 Effect of seed treatment with a combination of PGPR and Trichoderma strains on bacterial wilt incidence under greenhouse conditions

\begin{tabular}{lll}
\hline Treatments & Disease incidence (\%) & Disease protection (\%) \\
\hline Control & $98.1^{\mathrm{m}}$ & $0.0^{\mathrm{a}}$ \\
B. subtilis SE34 + T. asperellum T8 & $40.3^{\mathrm{def}}$ & $57.8^{\mathrm{hij}}$ \\
B. subtilis SE34 + T. harzianum UNS35 & $41.2^{\mathrm{efgh}}$ & $56.9^{\mathrm{fghi}}$ \\
B. subtilis SE34 + T. longibrachiatum UNS11 & $42.6^{\mathrm{jkl}}$ & $55.5^{\mathrm{bcd}}$ \\
B. subtilis SE34 + T. viride UNS42 & $41.4^{\mathrm{ghij}}$ & $56.7^{\mathrm{defg}}$ \\
B. amyloliquefaciens IN937a + T. asperellum T8 & $41.3^{\mathrm{fghi}}$ & $56.8^{\mathrm{efgh}}$ \\
B. amyloliquefaciens IN937a + T. harzianum UNS35 & $43.2^{\mathrm{l}}$ & $54.9^{\mathrm{b}}$ \\
B. amyloliquefaciens IN937a + T. longibrachiatum UNS11 & $40.2^{\mathrm{de}}$ & $57.9^{\mathrm{hij}}$ \\
B. amyloliquefaciens IN937a + T. viride UNS42 & $41.8^{\mathrm{ghijk}}$ & $56.3^{\mathrm{cdefg}}$ \\
P. fluorescens Pf3 + T. asperellum T8 & $38.3^{\mathrm{bc}}$ & $59.8^{\mathrm{kl}}$ \\
P. fluorescens Pf3 + T. harzianum UNS35 & $38.6^{\mathrm{bc}}$ & $59.5^{\mathrm{kl}}$ \\
P. fluorescens Pf3 + T. longibrachiatum UNS11 & $36.2^{\mathrm{a}}$ & $61.9^{\mathrm{m}}$ \\
P. fluorescens Pf3 + T. viride UNS42 & $38.8^{\mathrm{c}}$ & $59.3^{\mathrm{k}}$
\end{tabular}

Means of three replications, followed by the letters according to Duncan's multiple range tests (DMRT). Means sharing different alphabetical (a-m) superscripts in a column significantly different $(P<0.05)$. Control $-R$. solanacearum-treated plants

described that the B. amyloliquefaciens to significantly improve growth, disease suppression, and to elicit plant innate immunity. Three strains of PGPR, B. subtilis MBI600, GBO3, and Bacillus amyloliquefaciens IN937 have been reported as inducers against several plant pathogens in numerous field and vegetable crops (Zehnder et al. 2000; Beneduzi et al. 2012). The combined treatments of Pseudomonas sp., Bacillus sp., and T. harzianum were improved disease inhibition than their single treatment against bacterial wilt (Liu et al. 2014; Yendyo et al. 2017).
Effect of seed treatment with a combination of PGPR and Trichoderma sp. on bacterial wilt incidence under field conditions

Under field conditions, the outcomes showed that all the combined treatments offered maximum bacterial wilt protection over control. The percentage of wilt protection was recorded in combination with PGPR and Trichoderma sp. treatments ranged from 54 to $62 \%$. Among the combination treatments, $P$. fluorescens $\mathrm{Pf} 3+T$. longibrachiatum UNS11 exhibited maximum wilt protection of $62 \%$ than the control (97\% wilt incidence) (Table 3).

Table 3 Effect of seed treatment with combination of PGPR and Trichoderma strains on bacterial wilt incidence under field conditions

\begin{tabular}{|c|c|c|c|}
\hline Treatments & Disease incidence (\%) & Disease protection (\%) & Yield $\mathrm{kg} / \mathrm{m}^{2}$ \\
\hline Control & $96.8^{1}$ & $0.00^{\mathrm{a}}$ & $41.24^{\mathrm{a}}$ \\
\hline B. subtilis SE34 + T. asperellum T8 & $42.4^{\text {hij }}$ & $54.4^{\mathrm{cd}}$ & $129.32^{\text {de }}$ \\
\hline B. subtilis SE34 + T. harzianum UNS35 & $40.2^{\text {de }}$ & $56.6^{\text {ghi }}$ & $131.66^{\text {ef }}$ \\
\hline B. subtilis SE34 + T. longibrachiatum UNS11 & $41.9^{\text {ghij }}$ & $54.9^{\text {cdef }}$ & $127.76^{\mathrm{bc}}$ \\
\hline B. subtilis SE34 + T. viride UNS42 & $40.5^{\text {def }}$ & $56.3^{\mathrm{ghi}}$ & $132.84^{\mathrm{fg}}$ \\
\hline B. amyloliquefaciens IN937a + T. asperellum T8 & $41.4^{\mathrm{fghi}}$ & $55.4^{\text {defg }}$ & $128.42^{\text {de }}$ \\
\hline B. amyloliquefaciens IN937a + T. harzianum UNS35 & $42.5^{\mathrm{jk}}$ & $54.3^{\mathrm{bc}}$ & $131.73^{9}$ \\
\hline B. amyloliquefaciens IN937a + T. longibrachiatum UNS11 & $40.4^{\text {cdef }}$ & $56.4^{\text {ghi }}$ & $128.41^{\text {de }}$ \\
\hline B. amyloliquefaciens IN937a + T. viride UNS42 & $41.1^{\mathrm{efg}}$ & $55.7^{\mathrm{fgh}}$ & $131.36^{9}$ \\
\hline P. fluorescens Pf3 $+T$. asperellum T8 & $37.9^{b}$ & $58.9^{k}$ & $130.67^{\text {ef }}$ \\
\hline P. fluorescens Pf3 + T. harzianum UNS35 & $38.4^{\mathrm{b}}$ & $58.4^{k}$ & $131.81^{\mathrm{fg}}$ \\
\hline P. fluorescens Pf3 $+T$. longibrachiatum UNS11 & $35.2^{\mathrm{a}}$ & $61.6^{1}$ & $137.83^{\text {gh }}$ \\
\hline$P$. fluorescens Pf3 $+T$. viride UNS42 & $38.7^{\mathrm{bc}}$ & $58.1^{\mathrm{ijk}}$ & $130.35^{\mathrm{ef}}$ \\
\hline
\end{tabular}

Means of three replications, followed by the letters according to Duncan's multiple range tests (DMRT). Means sharing different alphabetical (a-l) superscripts in a column significantly different $(P<0.05)$. Control - $R$. solanacearum-treated plants 
Outcomes of the study showed that the combination of treatments of PGPR strains and Trichoderma sp. significantly increased the tomato yield. Maximum tomato yield was observed in combined treatment with $P$. fluorescens Pf3 $+T$. longibrachiatum UNS11 by $137.83 \mathrm{~kg} / \mathrm{m}^{2}$ as compared to other combinations and pathogen treatment $\left(41.24 \mathrm{~kg} / \mathrm{m}^{2}\right)$. The yields of tomato, treatment with $P$. fluorescens Pf $3+T$. longibrachiatum UNS11, were significantly increased by $70 \%$ as compared to the pathogen treatment (Table 3).

Earlier reports showed that combinations were more active than single treatment of whichever bacteria or fungi (Zheng et al. 2019). Recently, there are several root-associated beneficial microorganisms have been used to activate resistance against bacterial wilt in tomato (Kurabachew et al. 2013). Pre-treatment with several biotic and abiotic inducers induce plant defense response against pathogen attack in plants against plant viruses (Udayashankar et al. 2012), fungi (Jogaiah et al. 2018), and bacteria (Narasimha Murthy et al. 2018).

\section{Enzyme extraction and assay}

The PGPR and Trichoderma sp. influenced the changes in defense enzymes and the highest activities of POX and PPO enzymes occurred in different periods (Figs. 4, 5,6 , and 7). The study of wilt resistance in tomato seedlings combined treatments showed the maximum activity and expression of defense-related proteins against $R$. solanacearum. Treated tomato seedlings exhibited the expression of POX and PPO after post inoculation of $R$. solanacearum. A significantly higher POX and PPO enzyme activities were observed in combined treated with PGPR and Trichoderma strains when compared to single or individual treatments. The POX and PPO activities reached the maximum in all treatments at $36 \mathrm{~h}$ and $48 \mathrm{~h}$, respectively, after $R$. solanacearum inoculation and then slowly reduced. The POX and PPO enzyme activities were higher when combined with PGPR and Trichoderma strains, whereas no variation witnessed in untreated control seedlings (Figs. 4, 5, 6, and 7).

The treatment with beneficial microbes induces systemic resistance against bacterial wilt has already been reported by Jogaiah et al. (2013). The better induction of defense enzymes has been recommended as a mechanism accountable for the improved by the combination of beneficial microorganisms against bacterial wilt in tomato plants (Jetiyanon et al. 2007; Hyakumachi et al. 2013; Villena et al. 2018; Zheng et al. 2019). Increased activity of ISR induced by combination treatments may be due to the increased number of beneficial microbes involved in the treatment and moreover due to the cooperation among the strains. Several reports have designated that ET, SA, and JA signaling pathways are intricate in the beneficial microbe-mediated ISR against bacterial wilt (Takahashi et al. 2014). In the present study, results presented that combined treatments of PGPR and Trichoderma sp. were the maximum expression of defense enzymes against bacterial wilt in tomato. The combined

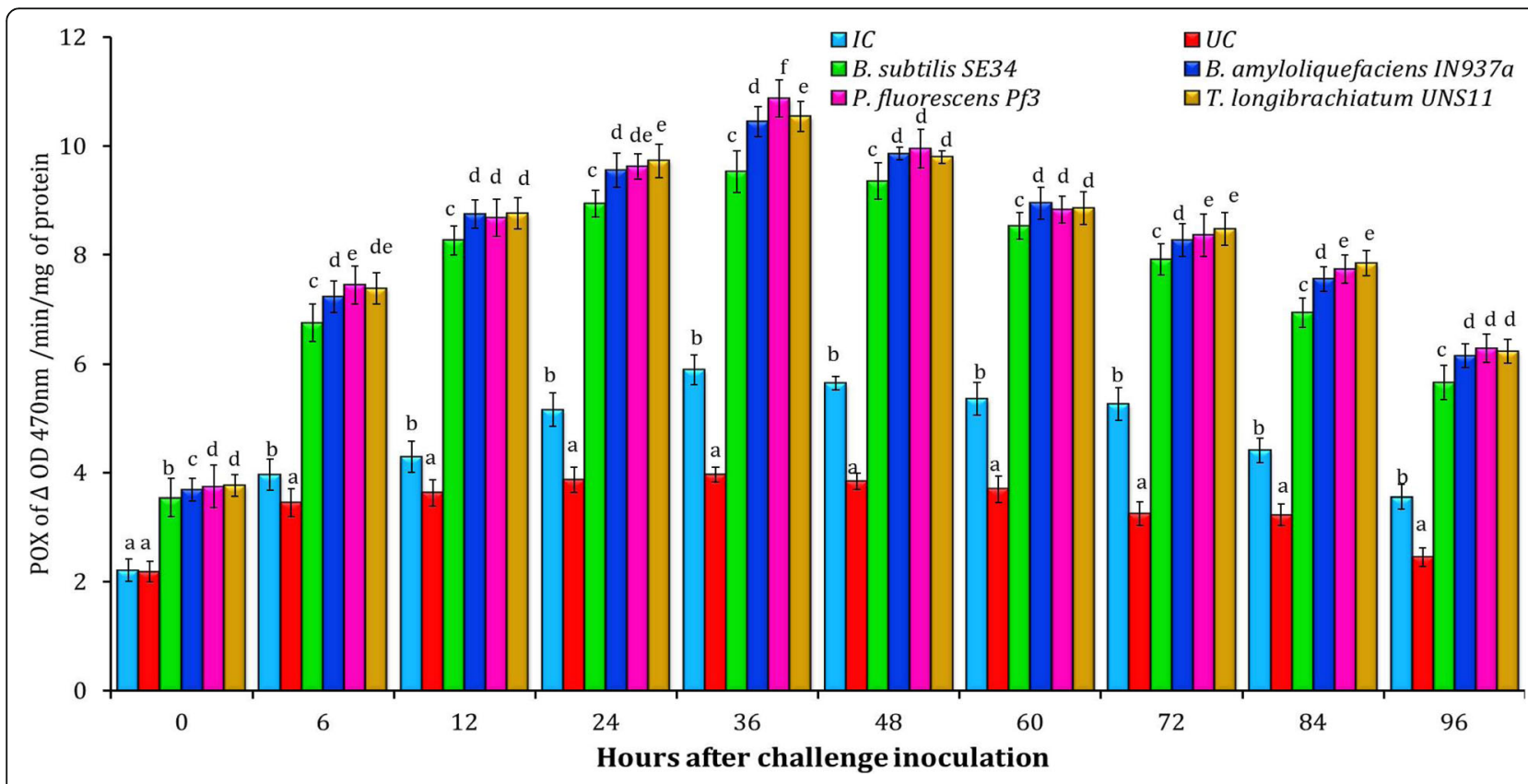

Fig. 4 The effect of PGPR and Trichoderma strains single or individual treatments on activity of peroxidase in tomato seedlings under greenhouse conditions. The values are the mean of three replications and bars represent standard errors. UC-uninoculated control, tomato seedlings without treatments and IC-inoculated control, tomato seedlings inoculated with $R$. solanacearum. Means of three replications, followed by the letters according to Duncan's multiple range tests (DMRT). Means sharing different alphabetical $(\mathbf{a}-\mathbf{f})$ in a column significantly different $(P<0.05)$ 


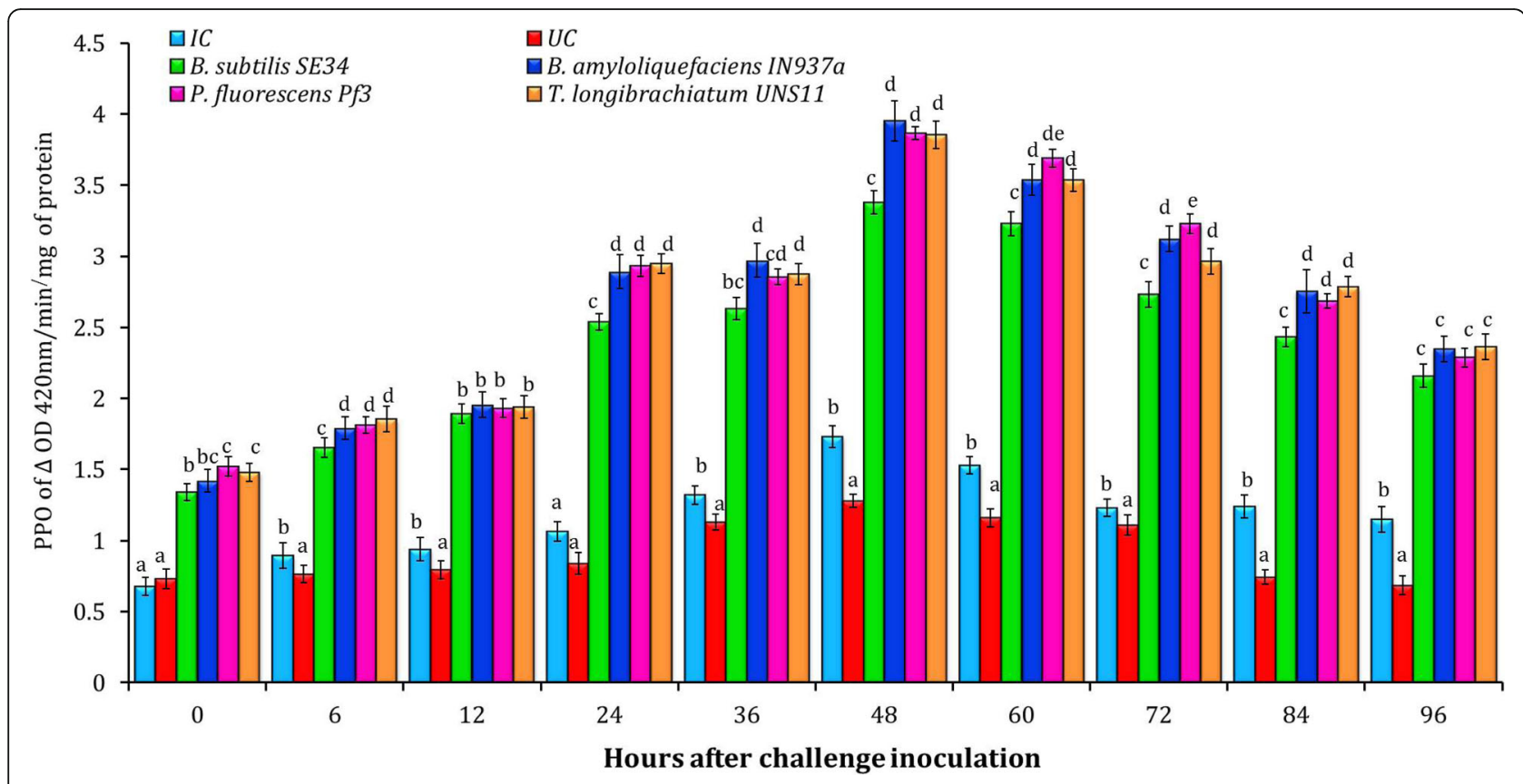

Fig. 5 The effect of PGPR and Trichoderma strains single or individual treatments on activity of polyphenol oxidase in tomato seedlings under greenhouse conditions. The values are the mean of three replications and bars represent standard errors. UC-uninoculated control, tomato seedlings without treatments and IC-inoculated control, tomato seedlings inoculated with $R$. solanacearum. Means of three replications, followed by the letters according to Duncan's multiple range tests (DMRT). Means sharing different alphabetical (a-d) in a column significantly different $(P$ $<0.05)$

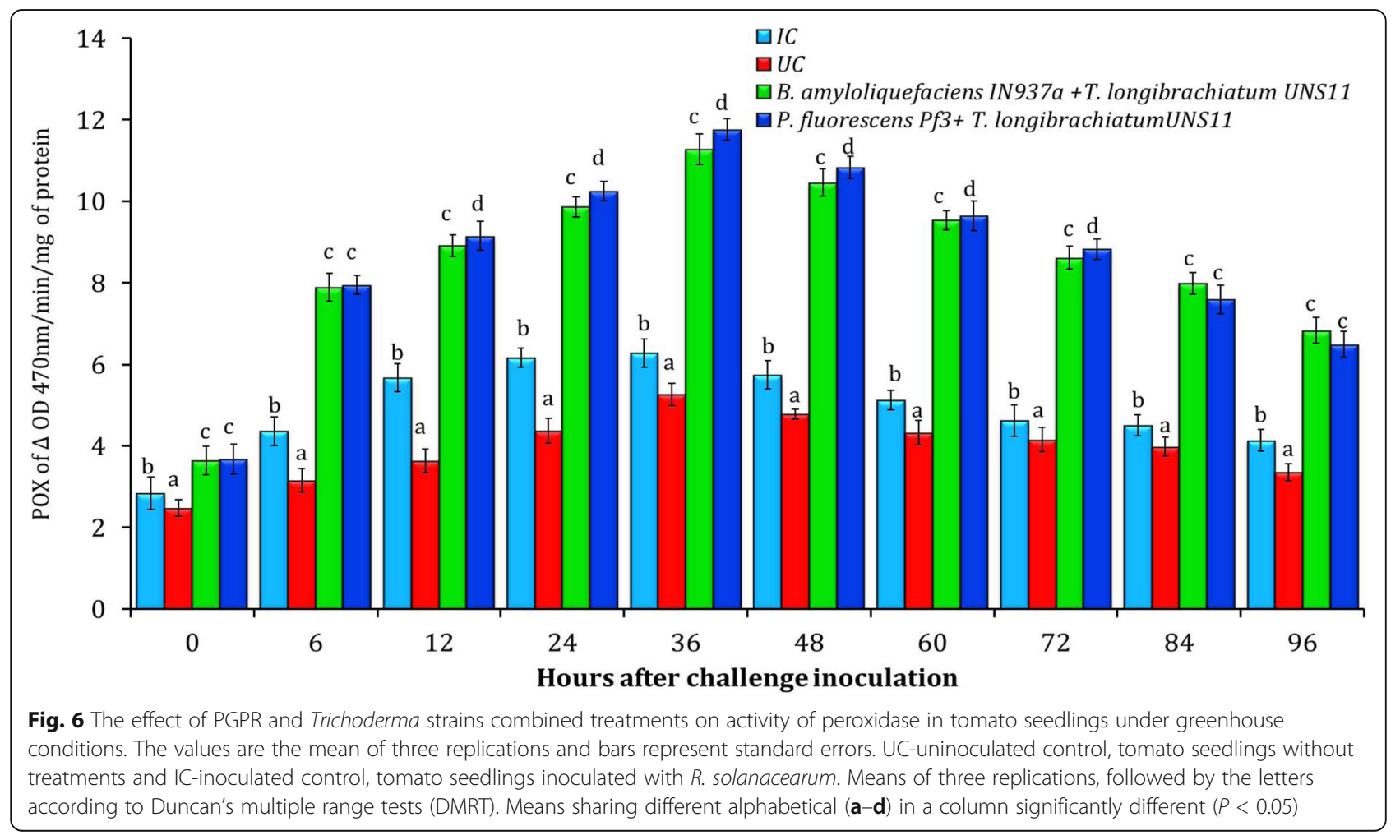




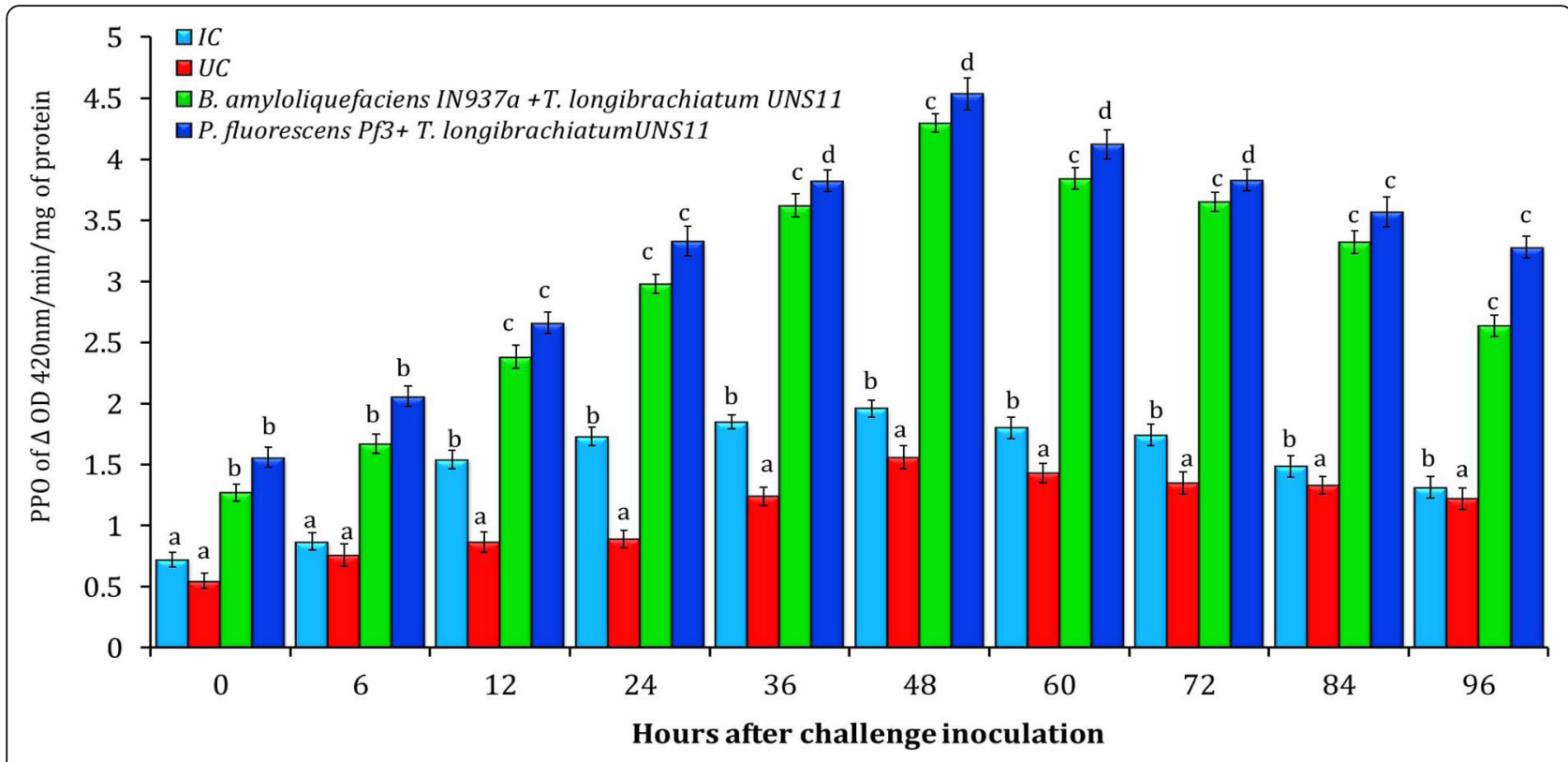

Fig. 7 Effect of PGPR and Trichoderma strains combined treatments on activity of polyphenol oxidase in tomato seedlings under greenhouse conditions. The values are the mean of three replications and bars represent standard errors. UC-uninoculated control and IC-inoculated control. Means of three replications, followed by the letters according to Duncan's multiple range tests (DMRT). Means sharing different alphabetical (a-d) in a column significantly different $(P<0.05)$

treated tomato seedlings exhibited the expression of POX and PPO enzymes after challenge inoculation of R. solanacearum. A significantly higher POX and PPO enzyme activities were recorded in combined treatment with PGPR and Trichoderma strains when compared to single or individual treatments, whereas no variation was witnessed in untreated control seedlings. Results achieved in the present investigation on integrated control of bacterial wilt of tomato designated that all the treatments were attempted significantly enhanced the seed germination, reduced the bacterial wilt frequencies over the controls. Several beneficial microorganisms may improve the level and steadiness by providing several mechanisms of action, more steady rhizosphere community, and be active over a broader range of ecological conditions (Mostafa et al. 2016 Marian et al. 2018).

\section{Conclusion}

In the present study, Bacillus sp., P. fluorescens sp., and Trichoderma sp. seemed to be the best biocontrol agents in controlling bacterial wilt caused by $R$. solanacearum. A total of 18 beneficial microorganisms were found effective under in vitro and in vivo conditions, individually and in combination treatments against the disease. The present findings can benefit farmers through increasing productivity, yield and income via reducing inputs, and nonchemical means in the face of bacterial wilt epidemics. It is an evident that beneficial microbes could possibly serve as eco-friendly and sustainable alternatives to the hazardous chemicals used for the management of plant diseases.

\section{Abbreviations}

PGPR: Plant growth-promoting rhizobacteria; PGPF: Plant growth-promoting fungi; ISR: Induced systemic resistance; SA: Salicylic acid; JA: Jasmonic acid; ET: Ethylene; POX: Peroxidase; PAL: Phenylalanine ammonialyase; PPO: Polyphenol oxidase; PDA: Potato dextrose agar; NA: Nutrient agar; CPG: Casaminoacid peptone glucose; CMC: Carboxymethyl cellulose; VI: Vigor index; ANOVA: Analysis of variance; DMRT: Duncan's multiple range tests

\section{Acknowledgements}

The authors are grateful to the University Grant Commission (UGC), New Delhi, India, for providing the UGC-BSR Meritorious Fellowship and PostDoctoral Fellowship (No. F.JPDFSS-2014-15-ST-KAR-7487) for the first author. The authors also like to thank the Department of Microbiology and Biotechnology, Bangalore University, Bangalore, and Department of Studies in Biotechnology, University of Mysore, Manasagangotri, and Mysore for providing the facilities for this research.

\section{Authors' contributions}

NK, SK and ACU were responsible for methodology, investigation and wrote the manuscript. CS and SRN were read the manuscript and made suitable changes. The author(s) read and approved the final manuscript.

\section{Funding}

University Grant Commission (UGC), New Delhi, Post-Doctoral Fellowship, ID No. F.JPDFSS-2014-15-ST-KAR-7487.

\section{Availability of data and materials}

All data of the study have been presented in the manuscript, and highquality and grade materials were used in this study.

Ethics approval and consent to participate Not applicable.

\section{Consent for publication}

Not applicable. 


\section{Competing interests}

The authors declare that they have no competing interests.

\section{Author details}

${ }^{1}$ Department of Studies in Biotechnology, University of Mysore, Manasagangotri, Mysore, Karnataka 570 006, India. ²Department of Microbiology, Field Marshal K. M. Cariappa College, A Constituent College of Mangalore University, Madikeri, Karnataka 571 201, India. ${ }^{3}$ Department of Microbiology and Biotechnology, Bangalore University, Jnana Bharathi Campus, Bangalore, Karnataka 560 056, India.

Received: 7 April 2020 Accepted: 29 July 2020

\section{Published online: 12 August 2020}

\section{References}

Abdelrahman M, Abdel-Motaal F, El-Sayed M, Jogaiah S, Shigyo M, Ito S, Tran LSP (2016) Dissection of Trichoderma longibrachiatum-induced defense in onion (Allium cepa L.) against Fusarium oxysporum f. sp. Cepaby target metabolite profiling. Plant Sci 246:128-138

Abdul-Baki AA, Anderson JD (1973) Vigour determination in soybean seed by multiple criteria. Crop Sci 13:630-633

Abo-Elyousr KAM, Khalil Bagy HMM, Hashem M et al (2019) Biological control of the tomato wilt caused by Clavibacter michiganensis subsp. michiganensis using formulated plant growth-promoting bacteria. Egypt J Biol Pest Control 29:54

Almaghrabi OA, MassoudSamia I, Abdelmoneim Tamer S (2013) Influence of inoculation with plant growth promoting rhizobacteria (PGPR) on tomato plant growth and nematode reproduction under greenhouse conditions. Saudi J BiolSci 20:57-61

Beneduzi A, Ambrosini A, Passaglia LM (2012) Plant growth-promoting rhizobacteria (PGPR): their potential as antagonists and biocontrol agents. Genetics Mol Biol 35(4):1044-1051

Boudyach EH, Fatmi M, Akhayat O, Benizri E, Aoumar AAB (2010) Selection of antagonistic bacteria of Clavibacter michiganensis subsp. michiganensis and evaluation of their efficiency against bacterial canker of tomato. Biocont Sci Tech 11:141-149

De-Britto S, Tanzeembanu DG, Praveen S, Lalitha S, Ramachandra YL, Jogaiah S, Ito $S$ (2020) Isolation and characterization of nutrient dependent pyocyanin from Pseudomonas aeruginosa and its dye and agrochemical properties. Sci Rep 10:1542

Devendra KC, Nabi SU, Dar MS, Khan KA (2018) Ralstonia solanacearum: a wide spread and global bacterial plant wilt pathogen. J Pharmaco Phytochem 7(2): $85-90$

Elphinstone JG (2005) The current bacterial wilt situation: a global overview. In: Allen C, Piror P, Hayward AC (eds) Bacterial wilt disease and the Ralstonia solanacearum. APS Press, St. Paul, pp 9-28

Elsayed TR, Jacquiod S, Nour EH, Sørensen SJ, Smalla K (2020) Biocontrol of bacterial wilt disease through complex interaction between tomato plant, antagonists, the indigenous rhizosphere microbiota, and Ralstonia solanacearum. Front Microbiol 10:2835

Hyakumachi M, Nishimura M, Arakawa T, Asano S, Yoshida S, Tsushima S, Takahashi H (2013) Bacillus thuringiensis suppresses bacterial wilt disease caused by Ralstonia solanacearum with systemic induction of defense-related gene expression in tomato. Microbes Environ 28:128-134

International Rules for Seed Testing (ISTA) (2003). In: Daper (ed) Rules 2003. International Seed Testing Association, Zurich, pp 1-520

Jayaraj J, Radhakrishnan N, Velazhahan R (2006) Development of formulations of Trichoderma harzianum strain M1 for control of damping-off of tomato caused by Pythium aphanidermatum. Arch Phytopathol Plant Protect 39(1):1-8

Jogaiah S, Abdelrahman M, Tran LP, Ito SI (2018) Different mechanisms of Trichoderma virens-mediated resistance in tomato against fusarium wilt involve the jasmonic and salicylic acid pathways. Mol Plant Pathol 19:870882

Jogaiah S, Abdelrahman M, Tran LS, Shinichi I (2013) Characterization of rhizosphere fungi that mediate resistance in tomato against bacterial wilt disease. J Exp Bot 64:3829-3842

Kloepper JW, Ryn CM, Zhang S (2004) Induced systemic resistance and promotion of plant growth by Bacillus spp. Phytopathol 94:1259-1266

Kurabachew H, Wydra K (2013) Characterization of plant growth promoting rhizobacteria and their potential as bioprotectant against tomato bacterial wilt caused by Ralstonia solanacearum. Biol Control 67:75-83
Latha P, Anand T, Ragupathi N, Prakasam V, Samiyappan R (2009) Antimicrobial activity of plant extracts and induction of systemic resistance in tomato plants by mixtures of PGPR strains and Zimmu leaf extract against Alternariasolani. Biol Control 50:85-93

Liu HX, Li SM, Luo YM et al (2014) Biological control of Ralstonia wilt, Phytophthora blight, meloidogyne root-knot on bell pepper by the combination of Bacillus subtilis AR12, Bacillus subtilis SM21 and Chryseobacterium sp. R89. Eur J Plant Pathol 139:107-116

Lowry OH, Rosebrough NH, Farr AL, Randall RJ (1951) Protein measurement with the folin phenol reagent. J Biol Chem 193:265-275

Maketon M, Apisitsantikul J, Siriraweekul C (2008) Greenhouse evaluation of Bacillus subtilis AP-01 and Trichoderma harzianum AP-001 in controlling tobacco diseases. Brazilian J Microbiol 39:296-300

Mansfield J, Genin S, Magori S, Citovsky V, Sriariyanum M, Ronald P, Dow M, Verdier V, Beer SV, Machado MA, Toth I, Salmond G, Foster GD (2012) Top 10 plant pathogenic bacteria in molecular plant pathology. Mol Plant Pathol 13: 614-629

Marian M, Nishioka T, Koyama H, Suga H, Shimizu M (2018) Biocontrol potential of Ralstonia sp. TCR112 and Mitsuaria sp. TWR114 against tomato bacterial wilt. Appl Soil Ecology 128:71-80

McPherson MR, Wang P, Marsh EL, Mitchell RB, Schachtman DP (2018) Isolation and analysis of microbial communities in soil, rhizosphere and roots in perennial grass experiments. J Visualized Exp Jo VE 137:57932

Milling A, Babujee L, Allen C (2011) Ralstonia solanacearum extracellular polysaccharide is a specific elicitor of defense responses in wilt resistant tomato plants. PLoS One 6:e15853

Mostafa A, Abdel-Motaal F, El-Sayed M, Jogaiah S, Shigyo M, Ito S-i, Tran L-SP (2016) Dissection of Trichoderma longibrachiatum-induced defense in onion (Allium cepa L.) against Fusarium oxysporum f. sp. Cepa by target metabolite profiling. Plant Sci 246:128-138

Narasimha Murthy K, Malini M, Fazilath U, Soumya K, Nayaka C, Niranjana SR, Srinivas C (2016) Lactic acid bacteria mediated induction of defense enzymes to enhance the resistance in tomato against Ralstonia solanacearum causing bacterial wilt. Sci Hortic 207:183-192

Narasimha Murthy K, Nirmala D, Srinivas C (2013) Efficacy of Trichoderma asperellum against Ralstonia solanacearum under greenhouse conditions. Ann Plant Sci 2:342-350

Narasimha Murthy K, Soumya K, Chandranayak S, Niranjana SR, Srinivas C (2018) Evaluation of biological efficacy of Trichoderma asperellum against tomato bacterial wilt caused by Ralstonia solanacearum. Egyptian J Biol Pest Control 28:63

Narasimha Murthy K, Srinivas C (2012) In vitro screening of bioantagonistic agents and plant extracts to control bacterial wilt (Ralstonia solanacearum) of tomato (Lycopersicon esculentum). Int J AgrTechnol 8: 999-1015

Nowicki M, Kozik EU, Foolad MR (2013) Late blight of tomato. Translational genomics for crop breeding, volume I: biotic stress. 1st ed. Varshney RK, Tuberosa, R. (eds) Wiley, Hoboken.

O'Brien PA (2017) Biological control of plant diseases. Australasian Plant Pathol 46:293-304

Prajapati HN, Panchal RK, Patel ST (2014) Efficacy of bioagents and biological interaction of Alternariasolani with phylloplane mycoflora of tomato. J Mycopathol Res 52:81-86

Ran LX, Liu CY, Wu GJ, van Loon LC, Bakker PAHM (2005) Suppression of bacterial wilt in Eucalyptus urophylla by fluorescent Pseudomonas spp. in China. Biol Control 32:111-120

Romera FJ, García MJ, Lucena C, Martínez-Medina A, Aparicio MA, Ramos J, Alcántara E, Angulo M, Pérez-Vicente R (2019) Induced systemic resistance (ISR) and Fe deficiency responses in dicot plants. Front Plant Sci 10:287

Satapute P, Milan VK, Shivakantkumar SA, Jogaiah S (2019) Influence of triazole pesticides on tillage soil microbial populations and metabolic changes. Sci Total Envi 651:2334-2344

Shoko Y, Soma S, Yumi K, Mai M, Suzuki S (2014) Impact of Bacillus amyloliquefaciens S13-3 on control of bacterial wilt and powdery mildewin tomato. Pest ManagSci 71:722-727

Takahashi H, Nakaho K, Ishihara T, Ando S, Wada T, Kanayama Y, Asano S, Yoshida S, Tsushima S, Hyakumachi M (2014) Transcriptional profile of tomato roots exhibiting Bacillus thuringiensis-induced resistance to Ralstonia solanacearum. Plant Cell Rep 33:99-110

Tan S, Dong Y, Liao H, Huang J, Song S, Xu Y et al (2013) Antagonistic bacterium Bacillus amyloliquefaciens induces resistance and controls the bacterial wilt of tomato. Pest ManagSci 69:1245-1252 
Tans-Kersten J, Huang H, Allen C (2001) Ralstonia solanacearum needs motility for invasive virulence on tomato. J Bacteriol 183:3597-3605

Thilagavathi R, Saravanakumar D, Ragupathi N, Samiyappan R (2007) A combination of biocontrol agents improves the management of dry root rot (Macrophom inaphaseolina) in greengram. Phytopathol Mediterr 46:157-167

Van-Loon LC (2007) Plant responses to plant growth-promoting rhizobacteria. European J Plant Pathol 119:243-254

Villena J, Kitazawa H, Van Wees SCM, Pieterse CMJ, Takahashi H (2018) Receptors and signaling pathways for recognition of bacteria in livestock and crops: prospects for beneficial microbes in healthy growth strategies. Front Immunol 9:2223

Wei Y, Moreno CC, Gongora TJ, Wang K, Sang Y, Duran RL, Macho AP (2018) The Ralstonia solanacearum csp22 peptide, but not flagellin-derived peptides, is perceived by plants from the Solanaceae family. Plant Biotechnol J 16:13491362

Wydra K, Semrau J (2005) Phenotypic and molecular characterization of the interaction of antagonistic bacteria with Ralstonia solanacearum causing tomato bacterial wilt. In: Zeller W, Ulrich C (eds) 1st international symposium on biological control of bacteria plant disease. Darmstadt, Germany, pp 112118

Yendyo S, Ramesh GC, Pandey BR (2017) Evaluation of Trichoderma spp., Pseudomonas fluorescens and Bacillus subtilis for biological control of Ralstonia wilt of tomato. F1000 res 6: 2028

Yuliar NYA, Toyota K (2015) Recent trends in control methods for bacterial wilt diseases caused by Ralstonia solanacearum. Microbes Environ 30:1-11

Zehnder GW, Yao C, Murphy JF, Sikora EJ, Kloepper JW (2000) Induction of resistance in tomato against cucumber mosaic cucumo virus by plant growth-promoting rhizobacteria. Biocontrol 45:127-137

Zhang Y, Hu ZJ et al (2020) Comparison of bacterial communities in soil samples with and without tomato bacterial wilt caused by Ralstonia solanacearum species complex. BMC Microbiol 20:89

Zheng X, Zhu Y, Wang J et al (2019) Combined use of a microbial restoration substrate and avirulent Ralstonia solanacearum for the control of tomato bacterial wilt. Sci Rep 9:20091

\section{Publisher's Note}

Springer Nature remains neutral with regard to jurisdictional claims in published maps and institutional affiliations.

\section{Submit your manuscript to a SpringerOpen ${ }^{\circ}$ journal and benefit from:}

- Convenient online submission

- Rigorous peer review

- Open access: articles freely available online

- High visibility within the field

- Retaining the copyright to your article

Submit your next manuscript at $\boldsymbol{\nabla}$ springeropen.com 